\title{
Interference film grown on stainless steel by pulsed current process using chromium free vanadate solution
}

\author{
Rosa Maria Junqueira ${ }^{1}$, Renata Braga Soares ${ }^{1}$, \\ Ricardo Adriano Dorledo de Faria, \\ Vanessa de Freitas Cunha Lins ${ }^{1}$
}

\footnotetext{
${ }^{1}$ Laboratório de Corrosão e Engenharia de Superfície - UFMG CP: 6627 - 13565-905, Belo Horizonte, MG e-mail: rosajunqueira@ufmg.br, renatabragasoares@yahoo.com.br, vlins@deq.ufmg.br
}

\begin{abstract}
Deposition of interference film is an alternative way for the formation of colored protective layers on the surface of stainless steels for decorative applications. The process involves growth of a chromium oxide film by electrochemical methods using in general sulphochromic solutions. However, it is well known that chromic acid contains $\mathrm{Cr}(\mathrm{VI})$, which is highly toxic, demanding special effluent treatments in order to avoid environmental pollution. The aim of the present work is to evaluate alternative chromium free solutions for coloration of stainless steel by an electrochemical method as a trial to avoid the $\mathrm{Cr}(\mathrm{VI})$ presence to achieve an environmentally friendly process. The morphology and corrosion resistance of the conversion coatings obtained from sodium vanadate solution were comparatively evaluated with a sample coloured in a sodium molybdate solution containing chromium and in a sulfochromic solution currently used in industrial coloration process. The corrosion behaviour of the colored samples was evaluated by using anodic potentiodynamic polarization and electrochemical impedance spectroscopy (EIS). The steel colored in a solution containing chromium and molybdenum ions showed the lowest corrosion resistance and a more porous and heterogeneous film than the other steel samples colored using vanadate and sulfochromic solutions. An electrochemical processing using a sodium vanadate solution can be a chromium free alternative for industrial application.
\end{abstract}

Keywords: interference film, Cr(VI), anodic polarization, colored stainless steel, EIS, FESEM.

\section{INTRODUCTION}

The surface finishing on stainless steels is an important attribute for architectural applications, and has great influence on its corrosion resistance [1,2]. The chemical and electrochemical coloration of stainless steels have been developed to produce thick passive films showing interference colors, and maintaining their metallic brightness.

The growth of interference films on stainless steels by chemical conversion of its surface is an alternative way for obtaining colored layers on its surface for decorative applications. In addition these coatings protect the substrate from corrosion by acting as an insulating barrier of low solubility between the metal surface and the environment.

The coloration process involves growth of a chromium oxide film by chemical or electrochemical methods using strong oxidizing solutions. This film is formed by a dissolution and precipitation process rather than by a reaction involving solid state diffusion. The formation of this film on the surface of the stainless steel occurs in three stages: steel dissolution prior to film formation until the steel becomes transpassive; film nucleation and growing of a $\mathrm{Cr}$-rich spinel oxide film; film growing until a thickness that coincides with the green color. After this point the film became undermined at the metal/film interface by excessive anodic dissolution and spalls or becomes detached spontaneously [3]. During the film growing the colors changing from bronze, brown, blue, gold, purple to green in this sequence, as the interference film thickness increases from $80 \mathrm{~nm}$ to $400 \mathrm{~nm}$, approximately. In addition, this thin passivation layer on stainless steel improves its corrosion resistance [1-5]. In general, the coloration solution of industrial processes contains hexavalent chromium, which is potentially carcinogenic, and for that reason demands rigid pollution control.

A chemical process for a spontaneous coloration of stainless steel by immersion in a hot solution containing a high concentration of chromic and sulphuric acids has being used since 1977 [2]. 
The disadvantage of this process is the use of an aggressive chromate solution at high temperature which will demand exhaustion of pollutants and promote corrosion of materials used in the coloration tank. For that reason, minimizing this rigorous condition, electrochemical methods have been proposed in which the stainless steel could be colored in a chromate and sulfuric acid solution at room temperature [6-8]. In general, the electrochemical process requires a shorter time for coloration than chemical processes and additionally provides more control of operational parameters, which results in more homogeneous colors of the stainless steel sheets [9].

Even though some of coloration electrochemical processes have a possibility of operating at room temperature, the presence of a $\mathrm{Cr}(\mathrm{VI})$ is a problem for environmental and human safety. It is well known that the chromate coatings can provide good protection for alloys, but hexavalent chromium has shown to be highly toxic and carcinogenic [6].The development of an environmentally friendly process is a necessity due to stringent environmental protection laws. For that reason some $\mathrm{Cr}(\mathrm{VI})$ free electrolytes for stainless steel coloration have already been tried [8]. These $\mathrm{Cr}$-free electrolytes could be made by a solution containing metal ions having a plurality of valence numbers such as water-soluble ions: $\mathrm{MnO}^{4-}, \mathrm{MoO}_{4}{ }^{2-}, \mathrm{V}_{5}, \mathrm{M}_{4} \mathrm{~V}_{2} \mathrm{O}_{7}$ and $\mathrm{M}_{3} \mathrm{VO}_{4}$, where $\mathrm{M}$ is a monovalent cation. However, there has been few published papers on molybdate and vanadate conversion coating treatments for $\mathrm{Mg}-\mathrm{Li}$ alloys and not for stainless steel [10].

The aim of the present work is to evaluate an alternative chromium free solution for coloration of stainless steel by electrochemical method as a trial to avoid or minimize the $\mathrm{Cr}(\mathrm{VI})$ presence to achieve an environmentally friendly process. The morphology and corrosion resistance of the conversion coatings obtained from two solutions: sodium molybdate and sodium vanadate were comparatively evaluated with a steel sample colored in an industrial sulphochromium solution.

\section{MATERIALS AND METHODS}

Specimens of $60 \times 40 \times 0.8 \mathrm{~mm}$ were cut from a sheet of bright buffing (BB) type AISI 304 stainless steel with a composition of C 0.03; Si 0.40; Mn 1.05; S 0.001; Cr 18.40; Ni 8.04 (wt.\%); and Fe balanced. The samples were degreased in ethanol, and rinsed in distilled water before immersion in three kinds of aqueous coloration solutions at $60^{\circ} \mathrm{C}$ temperature: (a) $0.1 \mathrm{M} \mathrm{CrO}_{3}$ and $5.0 \mathrm{M} \mathrm{H}_{2} \mathrm{SO}_{4}$, (b) $0.5 \mathrm{M} \mathrm{Na}_{3} \mathrm{VO}_{4}$ and $10 \mathrm{M} \mathrm{H}_{2} \mathrm{SO}_{4}$ and (c) $0.5 \mathrm{M} \mathrm{Na}_{2} \mathrm{MoO}_{4}$ and $3 \mathrm{M} \mathrm{H}_{2} \mathrm{SO}_{4}$ and $0.8 \mathrm{M} \mathrm{CrO}_{3}$.

The coloration of the samples were conducted in triplicate using a pulse current method. Alternating pulsed current with $\mathbf{0 . 1}$ Ad $\mathbf{~ m}^{-2}$ density having a square wave form was applied by means of a potenciostat/galvonastat PGSTAT302 from EchoChimie. The time for the electrodeposition of the interference films was controlled by duration in seconds of the anodic/cathodic pulse in 4/1ratio[11]. The colored specimens were fabricated with the same bronze color, ensuring that these interference colored films have identical thicknesses. In the coloration with the (c) solution it was necessary to put chromium in order to obtain the bronze color.

After the coloration, a cathodic hardening treatment was carried out at $0.5 \mathrm{~A} / \mathrm{dm}^{2}$ current density in aqueous solutions of $0.5 \mathrm{M} \mathrm{Na}_{3} \mathrm{VO}_{4}$ and $0.5 \mathrm{M} \mathrm{Na}_{2} \mathrm{MoO}_{4}+0.8 \mathrm{M} \mathrm{CrO}$ for the colored samples in the (b) and (c) solutions, respectively.

The stainless steel, before and after coloration, was cut to $20 \times 20 \times 0.8 \mathrm{~mm}$ sized samples for the electrochemical characterization essays in an aqueous $0.5 \mathrm{~mol} / \mathrm{L} \mathrm{NaCl}$ solution. The electrochemical measurements were performed using an AUTOLAB PGSTAT 302N potentiostat/galvanostat. The analysis was conducted on a conventional three-electrode cell, using platinum as a counter electrode and $\mathrm{Ag} / \mathrm{AgCl}$ as the reference electrode, and stainless steel, before and after coloration, as the working electrode. The steel samples were covered with artificial wax (Fluka), leaving an exposed area of $2 \mathrm{~cm}^{2}$. Before performing the assays, the samples were cleaned with water, purified by reverse osmosis, and acetone. All tests were performed in aerated solutions at room temperature. First, measurements of the open circuit potential (OCP) were taken over a 2 hour period. For the EIS measurements, an AC disturbance of $10 \mathrm{mV}$ was applied around the open circuit potential. The frequency range used was of $10^{4}$ to $10^{-2} \mathrm{~Hz}$ [12]. All impedance data were adjusted to equivalent circuits that were appropriate for use in Zview software. The quality of the adjustments was evaluated by chi-squared $(\chi 2)$ values. Anodic polarization experiments were carried out in $0.5 \mathrm{~mol} / \mathrm{L} \mathrm{NaCl}$ solution at a scanning rate of $0.167 \mathrm{mV} / \mathrm{s}$ until a potential higher than the pitting potential [13].

Surface morphology of the interference films was examined using a FESEM (Field Emission Scanning Electron Microscopy). Secondary electron images at magnifications of $150.000 \mathrm{X}$ were taken with a Quanta FEG 3D FEI microscope, operating at $5.0 \mathrm{kV}$. Higher operating voltages in the 5 to $15 \mathrm{kV}$ range caused damage to the film. 


\section{RESULTS AND DISCUSSION}

The electrochemical measurements were performed before and after coloration of stainless steel in order to evaluate the corrosion resistance of the interference films studied. After 2 hours of immersion, the OCP values showed stability for all steel samples (colored and bare steel). The OCP measurements are presented in figure 1 indicating a less noble potential for the sample colored in sodium molybdate solution followed by the bare stainless steel.

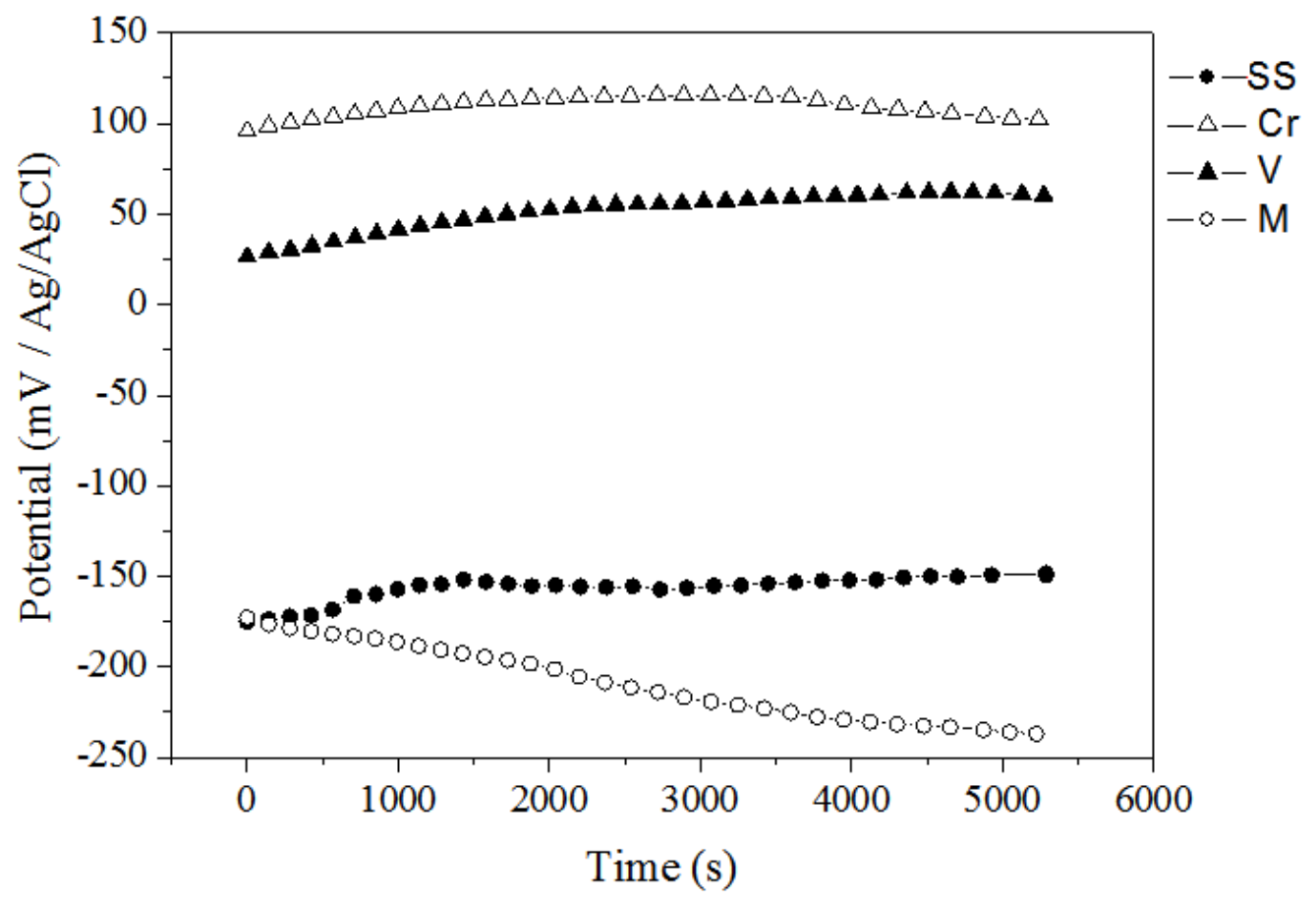

Figure 1: OCP curves in $0.5 \mathrm{~mol} / \mathrm{L} \mathrm{NaCl}$ for the bare steel (curve SS) and previously colored samples in $(\mathrm{Cr}) 0.1 \mathrm{M} \mathrm{CrO}$ $+5 \mathrm{M} \mathrm{H}_{2} \mathrm{SO}_{4}$, in (V) $0.5 \mathrm{M} \mathrm{Na}_{2} \mathrm{MoO}_{4}+\mathrm{H}_{2} \mathrm{SO}_{4} 5 \mathrm{M}$ and (M) $0.5 \mathrm{M} \mathrm{Na}_{3} \mathrm{VO}_{4}+\mathrm{H}_{2} \mathrm{SO}_{4} 5 \mathrm{M}$ solutions.

The typical potentiodynamic polarization curves of the bare stainless steel and the colored samples in three different coloration solutions are shown in Figure 2. The colored steel samples show a passive region with a passivation current density of two magnitude orders higher than the passivation current density of the bare steel. The steel colored in a molybdate solution showed a primary passive region of lower passivation current density and a secondary passive region, above $50 \mathrm{mV}$, with a higher passivation current density. The growth of the colored film in the molybdate solution led to a drop in the corrosion potential by $445 \mathrm{mV}$ in relation to the stainless steel sample colored by using sulfochromic solution and to an increase of the passivation current density in relation to all samples. 


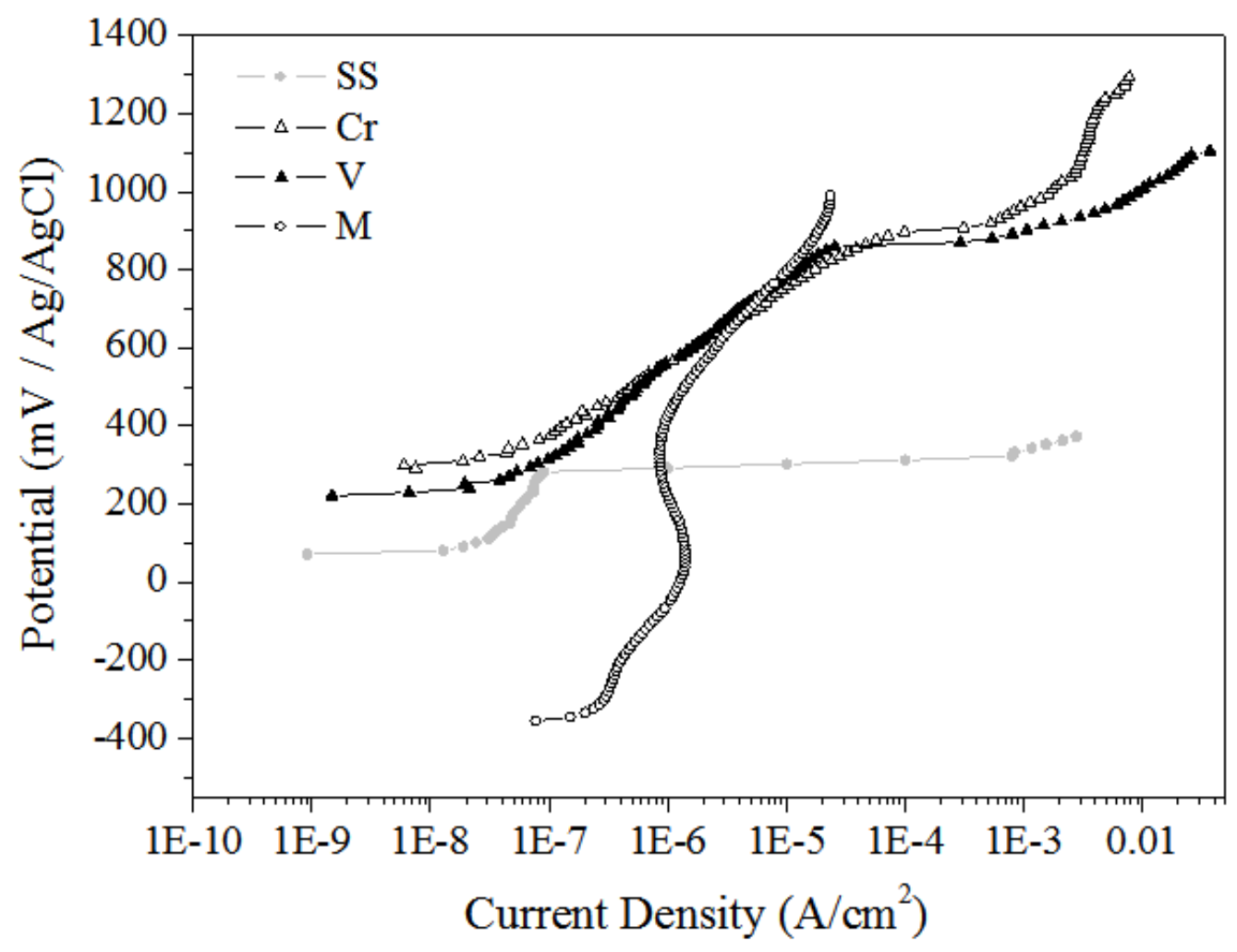

Figure 2: Potentiodynamic polarization curves obtained in $0.5 \mathrm{~mol} / \mathrm{L} \mathrm{NaCl}$ for the bare steel (curve SS) and previously colored samples in $(\mathrm{Cr}) 0.1 \mathrm{M} \mathrm{CrO}_{3}+5 \mathrm{M} \mathrm{H}_{2} \mathrm{SO}_{4}$, (V) $0.5 \mathrm{M} \mathrm{Na}_{3} \mathrm{VO}_{4}+\mathrm{H}_{2} \mathrm{SO}_{4} 5 \mathrm{M}$ and $0.5 \mathrm{M} \mathrm{Na}_{2} \mathrm{MoO}_{4}+0.8 \mathrm{M} \mathrm{CrO}+$ $\mathrm{H}_{2} \mathrm{SO}_{4} 5 \mathrm{M}$ and (M) solutions.

The values of Ecor, Epit and (Epit-Ecor) obtained from the potentiodynamic polarization curves are presented in Table 1. The difference between the pitting potential and the corrosion potential (Epit-Ecor) could be used to evaluate a material's susceptibility to pitting corrosion [4,14]. The (Epit-Ecor) values of $859.75 \pm 58.46 \mathrm{mV}$ and $901.31 \pm 61.29 \mathrm{mV}$ calculated for the samples colored in a vanadate solution and in a sulfochromic solutions, respectively, are similar, indicating that the vanadate solution can be a suitable alternative for chromate baths which are generally used in industrial coloration of stainless steel. The steel colored in the solution containing molybdenum showed the highest passive region but the passivation current density was the highest, demonstrating that the film is less efficient as a barrier against corrosion. The highest pitting potentials were shown by the steel colored by using Cr solution, followed by the steel colored in vanadate solution, respectively. The steel colored by using a molybdate solution showed the lowest pitting potential among the colored steels samples.

Table 1: Values of Ecor, Epit, and (Epit-Ecor) from potentidynamic polarization curves obtained in $0.5 \mathrm{~mol} / \mathrm{L} \mathrm{NaCl}$ for the bare steel (SS curve) and previously colored samples in (Cr) $0.1 \mathrm{M} \mathrm{CrO}_{3}+5 \mathrm{M} \mathrm{H}_{2} \mathrm{SO}_{4}, 0.5 \mathrm{M} \mathrm{Na}_{2} \mathrm{MoO}_{4}+0.8 \mathrm{M} \mathrm{CrO}{ }_{3}+$ $\mathrm{H}_{2} \mathrm{SO}_{4} 5 \mathrm{M}(\mathrm{M})$ and $0.5 \mathrm{M} \mathrm{Na} \mathrm{VO}_{4}+\mathrm{H}_{2} \mathrm{SO}_{4} 5 \mathrm{M}(\mathrm{V})$ solutions.

\begin{tabular}{ccccc}
\hline Samples & $\begin{array}{c}\text { Ecor/ } \\
\mathrm{mV}(\mathrm{Ag} / \mathrm{AgCl})\end{array}$ & $\begin{array}{c}\text { Epit/ } \\
\mathrm{mV}(\mathrm{Ag} / \mathrm{AgCl})\end{array}$ & $\begin{array}{c}\text { Epit- Ecor/ } \\
\mathrm{mV}(\mathrm{Ag} / \mathrm{AgCl})\end{array}$ & $\begin{array}{c}\text { Ipass/ } \\
\mathrm{A} / \mathrm{cm}^{2}\end{array}$ \\
\hline $\mathrm{SS}$ & $72.30 \pm 4.92$ & $285.41 \pm 19.41$ & $213.11 \pm 14.49$ & $5.40 \times 10-8 \pm 2.43 \times 10^{-9}$ \\
$\mathrm{Cr}$ & $298.20 \pm 20.28$ & $901.31 \pm 61.29$ & $603.11 \pm 41.01$ & $2.61 \times 10-6 \pm 4.21 \times 10^{-12}$ \\
$\mathrm{~V}$ & $223.61 \pm 15.21$ & $859.75 \pm 58.46$ & $636.14 \pm 43.26$ & $1.11 \times 10-6 \pm 0.36 \times 10^{-9}$ \\
$\mathrm{M}$ & $-351.80 \pm-23.92$ & $435.66 \pm 29.62$ & $787.46 \pm 53.55$ & $1.17 \times 10-6 \pm 0.91 \times 10^{-10}$ \\
\hline
\end{tabular}

In Figure 3 it was presented Nyquist diagrams of the bare steel and the colored samples evaluated in $0.5 \mathrm{~mol} / \mathrm{L} \mathrm{NaCl}$ solution. 


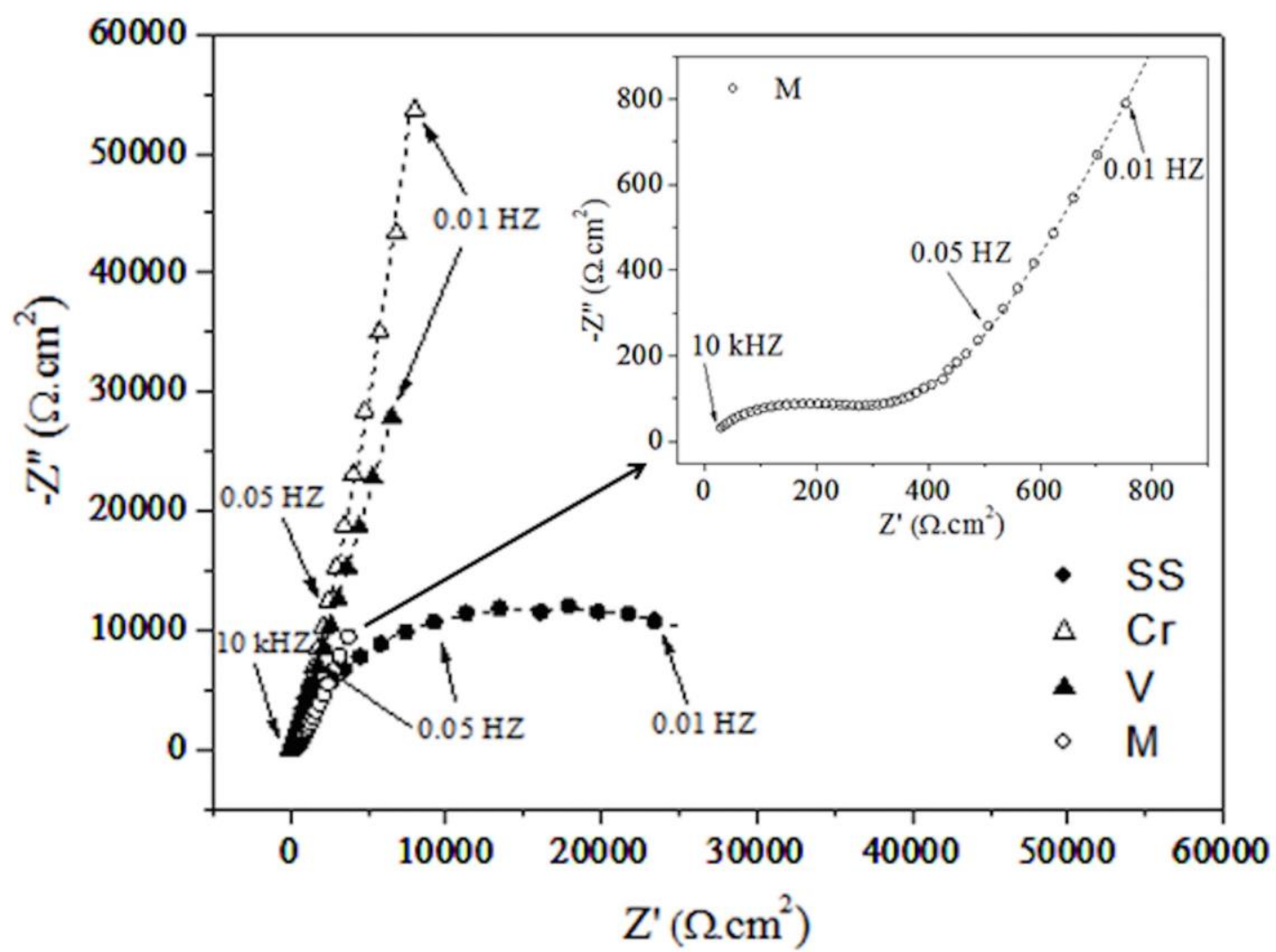

Figure 3: Nyquist diagrams in $0.5 \mathrm{~mol} / \mathrm{L} \mathrm{NaCl}$ for the bare steel ( $\mathrm{SS}$ curve) and previously colored samples in $(\mathrm{Cr}) 0.1 \mathrm{M}$ $\mathrm{CrO}_{3}+5 \mathrm{M} \mathrm{H}_{2} \mathrm{SO}_{4}$, (V) $0.5 \mathrm{M} \mathrm{Na}_{3} \mathrm{VO}_{4}+\mathrm{H}_{2} \mathrm{SO}_{4} 5 \mathrm{M}$ and (M) $0.5 \mathrm{M} \mathrm{Na} \mathrm{MoO}_{4}+0.8 \mathrm{M} \mathrm{CrO}_{3}+\mathrm{H}_{2} \mathrm{SO}_{4} 5 \mathrm{M}$ solutions.

The Bode diagrams of impedance modulus and of phase angle versus frequency of the bare steel and steels colored are shown in Figure 4 (a) and (b), respectively. Bode diagrams of phase angle versus frequency showed two maximum values indicating two time constants for all samples.
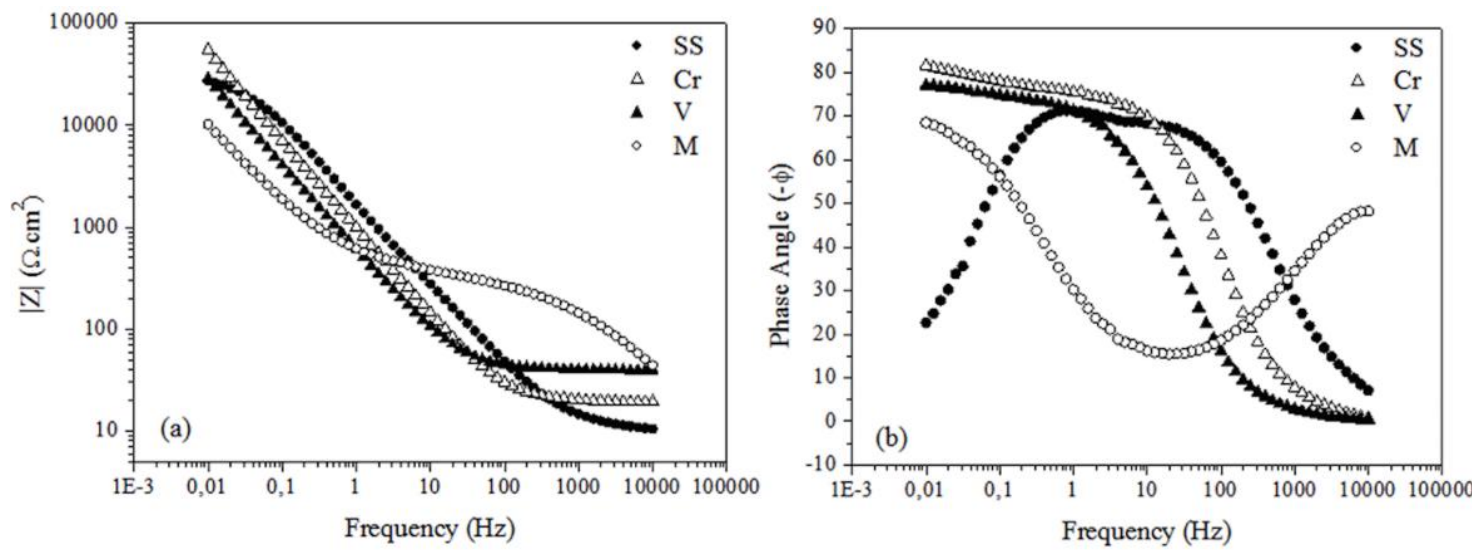

Figure 4: Bode diagrams of (a) impedance modulus and (b) phase angle in $0.5 \mathrm{~mol} / \mathrm{L} \mathrm{NaCl}$ for the bare steel (SS curve) and previously colored samples in $(\mathrm{Cr}) 0.1 \mathrm{M} \mathrm{CrO} 3+5 \mathrm{M} \mathrm{H}_{2} \mathrm{SO}_{4}$, and, (V) $0.5 \mathrm{M} \mathrm{Na}_{3} \mathrm{VO}_{4}+\mathrm{H}_{2} \mathrm{SO}_{4} 5 \mathrm{M}$ and (M) $0.5 \mathrm{M}$ $\mathrm{Na}_{2} \mathrm{MoO}_{4}+0.8 \mathrm{M} \mathrm{CrO}_{3}+\mathrm{H}_{2} \mathrm{SO}_{4} 5 \mathrm{M}$ solutions.

In Table 2 it was presented the electrochemical parameters obtained from electrochemical impedance spectroscopy analysis. 
Table 2: Electrochemical parameters obtained from impedance curves in $0.5 \mathrm{~mol} / \mathrm{L} \mathrm{NaCl}$ for the bare steel (SS curve) and previously colored samples in $(\mathrm{Cr}) 0.1 \mathrm{M} \mathrm{CrO} \mathrm{Cr} \mathrm{H}_{2}+5 \mathrm{M} \mathrm{HO}_{4}$, , (V) $0.5 \mathrm{M} \mathrm{Na}_{3} \mathrm{VO}_{4}+\mathrm{H}_{2} \mathrm{SO}_{4} 5 \mathrm{M}$ and (M) $0.5 \mathrm{M}$ $\mathrm{Na}_{2} \mathrm{MoO}_{4}+0.8 \mathrm{M} \mathrm{CrO}_{3}+\mathrm{H}_{2} \mathrm{SO}_{4} 5 \mathrm{M}$ solutions.

\begin{tabular}{ccccccc}
\hline Samples & $\mathrm{R} 1 / \Omega . \mathrm{cm}^{2}$ & $\mathrm{R} 2 / \Omega . \mathrm{cm}^{2}$ & $\mathrm{R} 3 / \Omega . \mathrm{cm}^{2}$ & $\mathrm{~W} / \Omega . \mathrm{cm}^{2}$ & $\mathrm{CPE} 1 / \mathrm{F} . \mathrm{cm}^{2}$ & $\mathrm{CPE} 2 / \mathrm{F} . \mathrm{cm}^{2}$ \\
\hline \multirow{2}{*}{$\mathrm{SS}$} & 10.60 & $3.67 \times 10^{2}$ & $3.35 \times 10^{4}$ & & $1.27 \times 10^{-4}$ & $5.81 \times 10^{-13}$ \\
& \pm 0.17 & $\pm 0.21 \times 10^{2}$ & $\pm 2.28 \times 10^{3}$ & - & $\pm 3.95 \times 10^{-7}$ & $\pm 3.35 \times 10^{-15}$ \\
& 19.46 & $5.98 \times 10^{4}$ & $1.05 \times 10^{20}$ & & $2.08 \times 10^{-4}$ & $3.38 \times 10^{-7}$ \\
$\mathrm{Cr}$ & \pm 0.89 & $\pm 1.34 \times 10^{3}$ & $\pm 5.33 \times 10^{17}$ & - & $\pm 3.66 \times 10^{-5}$ & $\pm 3.27 \times 10^{-8}$ \\
& 12.26 & $2.76 \times 10^{1}$ & $1.02 \times 10^{20}$ & & $5.63 \times 10^{-7}$ & $3.60 \times 10^{-4}$ \\
$\mathrm{~V}$ & \pm 0.45 & $\pm 0.25 \times 10^{1}$ & $\pm 6.12 \times 10^{18}$ & - & $\pm 3.20 \times 10^{-8}$ & $\pm 4.57 \times 10^{-5}$ \\
& 13.5 & $2.40 \times 10^{2}$ & $2.72 \times 10^{2}$ & $1.13 \times 10^{5}$ & $8.48 \times 10^{-6}$ & $1.75 \times 10^{-4}$ \\
$\mathrm{M}$ & \pm 0.29 & $\pm 0.15 \times 10^{2}$ & $\pm 0.16 \times 10^{2}$ & $\pm 7.68 \times 10^{3}$ & $\pm 1.01 \times 10^{-7}$ & $\pm 3.29 \times 10^{-6}$ \\
\hline
\end{tabular}

The polarization resistance values for the bare steel, for the sample colored in the vanadate solution, and in the sulfochromic solution were obtained by fitting the EIS data to the equivalent circuit shown in Figure 5 (a). For the sample colored in the molybdate solution, polarization resistance was obtained by fitting the EIS data to the equivalent circuit shown in Figure 5 (b). The EIS results were interpreted in terms of equivalent electrical circuits shown in Figure 5, where R1 is the resistance due to bulk solution, R2 and CPE1 are the impedance and the constant phase element associated to the interference film, W is the Warburg impedance, R3 and CPE2 are the impedance and the constant phase element associated to the corrosion process occurring at the metal/oxide interface $[15,16]$.

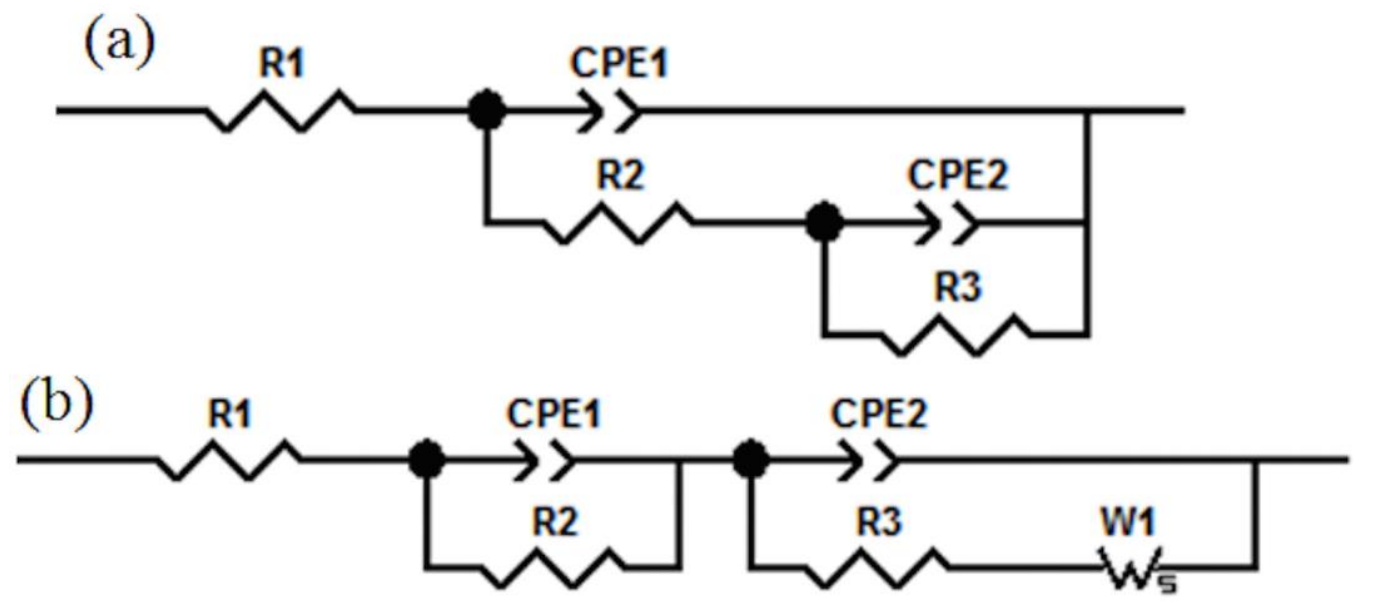

Figure 5: Equivalent circuits for the corrosion behavior of (a) the bare steel, previously colored samples in $(\mathrm{Cr}) 0.1 \mathrm{M}$ $\mathrm{CrO}_{3}+5 \mathrm{M} \mathrm{H}_{2} \mathrm{SO}_{4}$ and (M) $0.5 \mathrm{M} \mathrm{Na}_{2} \mathrm{MoO}_{4}+0.8 \mathrm{M} \mathrm{CrO}_{3}+\mathrm{H}_{2} \mathrm{SO}_{4} 5 \mathrm{M}$ solutions and (b) previously colored sample in $0.5 \mathrm{M} \mathrm{Na}_{3} \mathrm{VO}_{4}+\mathrm{H}_{2} \mathrm{SO}_{4} 5 \mathrm{M}$ solution.

The sample colored in the molybdate solution showed the lowest values of polarization resistance, and the sample colored by using sulfochromic and vanadate solutions showed the highest values of polarization resistance (Figure 3 and Table 2). The equivalent circuit fitted to the EIS data for the steel colored with the vanadate solution was associated to an impedance due to the interference film and a corrosion process occurring through pores in the oxide film. The equivalent circuit fitted to the EIS data of steel colored by using the molybdate solution corresponds to impedance due to the interference film and to the corrosion process occurring at the metal/film interface controlled by a diffusion process.

A comparative analysis of the FESEM images of Figure 6 indicates a more porous structure for the sample colored in the molybdate solution than in the vanadate solution. The lowest value of pitting potential and impedance of steel colored by using molybdate solution in relation to the steels colored by using sulfochromic and vanadate solutions are in accordance with SEM micrographs that indicate that the interference film formed in molybdate solutions are less compact and homogeneous than the interference films produced in $\mathrm{Cr}$ and vanadate solutions. It was reported that molybdate species adsorbed at the film solution interface catalyzes the transpassive dissolution of $\mathrm{Cr}$ from the alloys [17]. The molybdate and vanadate species act as oxidizing agents for producing the passive film. They were not incorporated into the passive film constituted by $\mathrm{Cr}$ and $\mathrm{Fe}$ oxides/hydroxides [18-21]. Besides, the electrolyte composition influenced the chemical prop- 
erties of the passive film, as observed. To our knowledge, the effect of vanadate species on the properties of the interference film was not found in literature.
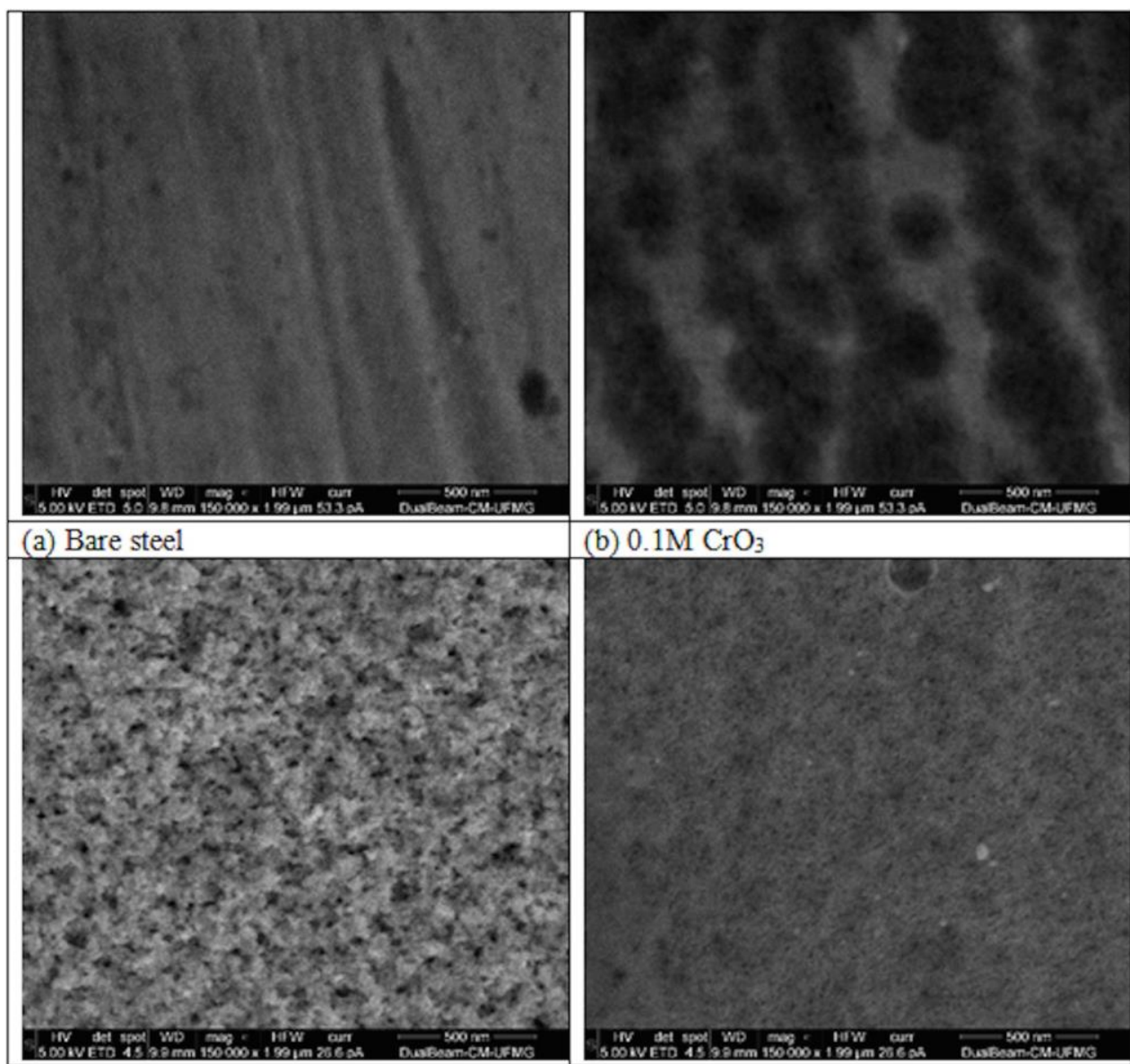

\section{(b) $0.1 \mathrm{M} \mathrm{CrO}_{3}$}

(c) $0.5 \mathrm{MNa}_{2} \mathrm{MoO}_{4}$

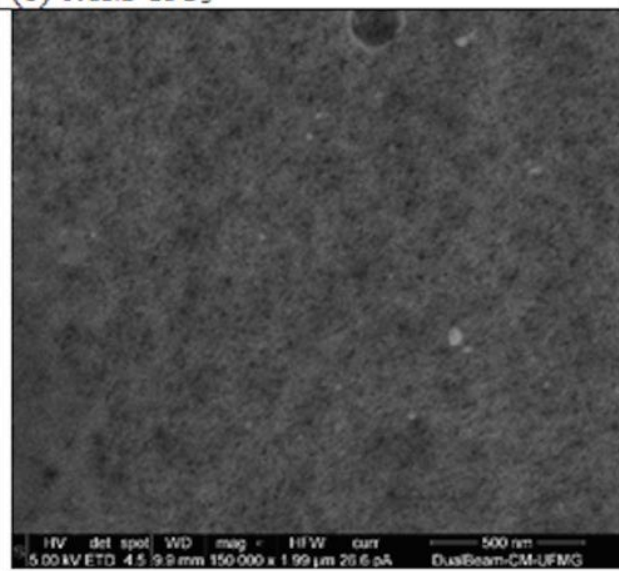

(d) $0.5 \mathrm{MNa}_{3} \mathrm{VO}_{4}$

Figure 6: FESEM images of a stainless steel (a) before, and after coloration in (b) $0.1 \mathrm{M} \mathrm{CrO}_{3}+5 \mathrm{M} \mathrm{H}_{2} \mathrm{SO}_{4}$ and (c) $0.5 \mathrm{M}$ $\mathrm{Na}_{2} \mathrm{MoO}_{4}+0.8 \mathrm{M} \mathrm{CrO}_{3}+\mathrm{H}_{2} \mathrm{SO}_{4} 5 \mathrm{M}$ and (d) $0.5 \mathrm{M} \mathrm{Na}_{3} \mathrm{VO}_{4}+\mathrm{H}_{2} \mathrm{SO}_{4} 5 \mathrm{M}$.

\section{CONCLUSIONS}

The susceptibility to pitting corrosion was practically the same for the sample colored in vanadate solution and to the sample colored in sulfochromic solution.

The analysis of EIS data showed that the sample colored in the molybdate solution had the lowest values of polarization resistance, and the sample colored by using sulfochromic and vanadate solutions had the highest values of polarization resistance.

The FESEM analysis indicates a more porous structure for the sample colored in molybdate solution than in vanadate solution, which could be associated with a lower corrosion resistance of this sample compared with the sample colored in vanadate solution.

The results obtained shows that an electrochemical process using sodium vanadate solution could be a chromium free alternative for industrial application providing an environmentally friendly process for coloration of stainless steel.

\section{ACKNOWLEDGEMENTS}

The authors gratefully acknowledge FAPEMIG - Fundação de Amparo à Pesquisa do Estado de Minas Gerais (Proc. PPM-00083-14) and CNPq (Proc. 310444/2013-6) for the support. The Center of Microscopy of UFMG for the FESEM images.

\section{BIBLIOGRAPHY}

[1] JUNQUEIRA, R. M. R, ANDRADE, M. S., LOUREIRO, C. R. O., et al., "The chemical and mechanical characteristics of thermally aged interference thin films on stainless steel", Surface and Coatings Technology, 
v. 203, n. 13, pp. 1908-1912, Mar. 2009.

[2] EVANS, T. E., "Film formation on stainless steel in a solution containing chromic and sulphuric acids", Corrosion Science, v. 17, n. 2, pp. 105-124, Dec. 1977.

[3] EVANS, T. E., HART, A. C., SKEDGELL, A. E., "The nature of the film on coloured stainless steel", Transactions of the Institute of Metal Finishing, v. 51, pp. 108, 1973.

[4] CONRRADO, R., BOCCHI, N., ROCHA-FILHO, R. C., et al., "Corrosion resistance of colored films grown on stainless steel by the alternating potential pulse method", Electrochimica Acta, v. 48, n. 17, pp. 2417-2424, Jul. 2003.

[5] EVANS, T. E., HART, A. C., JAMES, H., et al., "A new process for colouring stainless steel", Electrochimica Acta, v. 50, pp. 77, Jan. 1972.

[6] OGURA, K., LOU, W., NAKAYAMA, M., "Coloration of stainless steel at room temperature by triangular current scan method", Electrochimica Acta, v. 41, n. 18, pp. 2849-2853, 1996.

[7] JUNQUEIRA, R. M. R., ANDRADE, M. S., LOUREIRO, C. R. O., et al., "Mechanical properties of interference thin films on colored stainlesssteel evaluated by depth-sensing nanoindentation", Surface and Coatings Technology, v. 201, n.6, pp. 2431-2437, Dec. 2006.

[8] VASCONCELOS, K. O., BOCCHI, N., SIMÕES, A. M., "Pitting corrosion resistance of coloured oxide films grown on stainless steel in sulphuric acid in the presence and absence of chromic acid", Journal of the Brazilian Chemical Society, v. 21, n. 3, pp. 469-475, 2010.

[9] SONE, Y., WADA, K., KURAHASHI, H., et al., "Method of manufacturig colored stainless steel materials and apparatus for continuously manufacturing same", EP. Pat. 0204846 B1, jun/1991.

[10] SONE, Y., WADA, K., KURAHASHI, H., et al., "Method of manufacturing colored stainless steel", EP. Pat. 0204846A1, nov/1985.

[11] JUNQUEIRA, R. M. R., MANFRIDINI, A. P. A., LOUREIRO, C. R. O., et al., "Morphological, chemical and mechanical characteristics of an anodic coating on stainless steel", Surface Engineering, v. 29, n.5, pp. 379-383, Feb. 2013.

[12] AMERICAN SOCIETY FOR TESTING AND MATERIALS, STP 1188, Electrochemical Impedance: Analysis and Interpretation, 1993.

[13] AMERICAN SOCIETY FOR TESTING AND MATERIALS, G5-94: Test Method for Making Potentiostatic and Potentiodynamic Anodic Polarization Measurements, 1994.

[14] CORREDOR, J., BERGMAN, C. P., PEREIRA, M., et al., "Coloring ferritic stainless steel by an electrochemical-photochemical process under visible light illumination", Surface and Coatings Technology, v. 245, pp. 125-132, Mar. 2014.

[15] HOSEINPOOR, M., MOMENI, M., MOAYED, M. H., et al., "EIS assessment of critical pitting temperature of 2205 duplex stainless steel in acidified ferric chloride solution", Corrosion Science, v. 80, pp. 197, 2014.

[16] AZZI, M., BENKAHOUL, M., KLEMBERG-SAPIEHA, J. E., et al., "Corrosion and mechanical properties of duplex-treated 301 stainless steel", Surface and Coatings Technology, v. 205, n.5, pp. 1557, Nov. 2010.

[17] BOJINOV, M., BETOVA, I., RAICHEFF, R., "Influence of molybdenum on the transpassivity of a fe + $12 \%$ cr alloy in $\mathrm{H}_{2} \mathrm{SO}_{4}$ solutions", Journal of Electroanalytical Chemistry., v. 430, n.1-2, pp. 169-178, Jun. 1997.

[18] FUJIMOTO, S., TSUJINO, K., SHIBATA, T., "Growth and properties of cr-rich thick and porous oxide films on type 304 stainless steel formed by square wave potential pulse polarisation", Electrochimica Acta, v. 47, n. 4, pp. 543-551, Nov. 2001.

[19] KIKUTI, E., BOCCHI, N., PASTOL, J. L., et al., "Composition and structure of coloured oxide films on stainless steel formed by triangular current scan and cathodic hardening treatment", Corrosion Science, v. 49, n.5, pp. 2303-2314, May. 2007.

[20] KIKUTI, E., CONRRADO, R., BOCCHI, N., et al., "Chemical and electrochemical coloration of stainless steel and pitting corrosion resistance studies", Journal of the Brazilian Chemical Society, v. 15, n. 4, pp. 472-480, Jul/Aug. 2004.

[21] BOJINOV, M., FABRICIUS, G., LAITINEN, T., et al., "Transpassivity mechanism of iron-chromiummolybdenum alloys studied by AC impedance, DC resistance and RRDE measurements", Electrochimica Acta, v. 31, n.24, pp. 4331-4343, Jul. 1999. 